\title{
Pimenta Bueno, o Constitucionalista do Império.
}

\author{
Manoel Gonçalves Ferreira Filho \\ Professor Titular de Direito Constitucional \\ na Faculdade de Direito da Universidade \\ de São Paulo
}

A grandeza da Academia do Largo de São Francisco não foi construída apenas pelos mestres que nela ensinaram. A maior parte de sua glória foi conquistada por discípulos seus que se destacaram nos mais variados setores da atividade. Poetas como ÁLVARES DE AZEVEDO, estadistas como RODRIGUES ALVES, juristas como LAFAIETE. Assim, nas comemorações do sesquicentenário, cumpre ressaltar a figura do estudante que mais tarde ilustrou a história brasileira e conseqüentemente exaltou a casa de onde proveio. $\mathrm{E}$ sem dúvida não é injusto personalizar essa homenagem em um dos mais eminentes e em um dos que primeiro se avantajaram dentre os bacharéis da Faculdade de Direito: PIMENTa BuEno, o MARQUÊS DE SÃO VICENTE.

Paulista e paulistano, José ANTônio PIMENTA BUENo pertence à segunda turma da Faculdade do Largo de São Francisco. Nela ingressou em 1828, dela saiu formado em 1832. Por isso o seu êxito, como jurista, diplomata, político e homem de estado, foi dos que mais cedo honraram a Academia, consagrando-a como escola não só de Direito mas também de espírito público. "De mediana estatura, pálido, pouca barba, cabelos pretos, nada formoso, já em moço. Quanto ao caráter - bondoso e sociável, delicado para com todos, especialmente para com o belo sexo. Tinha a locução difícil, e defeituosa a dicção. Trocava os "ll" por "rr". Assim o descreve AlmEIDA NoGUEIRA, nas Tradições e Reminiscências da Academia de São Paulo, essa descrição em que se vê o típico paulista acaboclado, modesto e introspectivo.

Essa modéstia levou-o a não procurar de pronto o doutoramento, a que o animavam os mestres, impressionados com 
as qualidades de jurisconsulto que durante o curso repontaram. Somente o fez em 1843. Antes disso, porém, o serviço público já o convocara e, inclusive, o guindara, por breve período, à presidência da Província de Mato Grosso em 1835.

Em 1844, confiou-lhe o Governo imperial tarefa tão delicada quão difícil, ou seja, representar diplomaticamente o Brasil junto ao ditador paraguaio, Carlos Lopez, pai de Solano Lopez. E nessa missão obteve pleno êxito, a ponto de ganhar notória influência sobre o governante estrangeiro, para indignação da imprensa de Buenos Aires, sempre ciumenta do prestígio brasileiro na terra dos guaranis.

Daí por diante acumularam-se os triunfos em sua vida pública. Foi Presidente do Conselho de Ministros em 1870, depois de ministro de estrangeiros e da justiça no gabinete de 22 de maio de 1847. Foi deputado e senador por São Paulo, nomeado em 1853. Foi magistrado, aposentando-se como ministro do Supremo Tribunal de Justiça. Pertenceu ao Conselho de Estado. E não lhe faltaram as honrarias: Visconde e depois Marquês de São Vicente.

Jurista de escol, foi o maior dos constitucionalistas do Império. Autor do Direito Público Brasileiro e Análise da Constituição do Império, publicado em 1858, muitas de suas lições merecem ainda hoje a ponderação e o exame dos que se debruçam sobre o problema constitucional brasileiro. Essa obra - é SEABRA FAGUNDES quem o sublinha na Apresentação que precede sua reedição promovida pelo Ministério da Justiça em comemoração ao seu centenário - "se credencia, antes de tudo, pela fidelidade ao sentido impessoal e superior da ordem jurídica, pelo espírito crítico, desassombrado e lúcido, a serviço do aperfeiçoamento das instituições constitucionais e, ainda, pela capacidade de dar vida aos textos na adequação deles ao estágio político e social do país na época".

O ponto mais saliente da Carta de 25 de março de 1824 está na previsão de um quarto poder: o poder moderador. Filia-se nisso à lição de CoNsTANT que não repudia a separação de poderes à moda de MoNTESQUIEU mas a completa por um poder neutro que vele sobre os supremos interesses do país e previna ou solucione os eventuais conflitos que oponham os três poderes: Legislativo, Executivo e Judiciário.

Preocupado em assegurar a liberdade contra o Estado, MONTESQUIEU dera fórmula clássica à idéia de que só o poder é capaz de deter ou conter o poder. Por isso, pregara a divisão no Espírito das Leis (livro XI, cap. VI) no exercício do poder 
estatal entre um Legislativo, que declarasse as leis por que se limitaria a atuação dos homens, um Executivo que acompanhasse o seu cumprimento, a sua execução e um Judiciário que julgasse segundo essas normas. Com isso pretendia propiciar a liberdade política, ou seja, "a tranqüilidade de espírito que provém da opinião que cada um tem de sua segurança", segurança que em última análise resultaria da improbabilidade do abuso. Abuso improvável, pois dependente de um conluio também improvável entre Legislativo, Executivo e Judiciário.

Não preocupou a MoNTESQUIEU a gravidade de um conflito entre esses poderes. Minimizou-o, ao contrário, por supor que "pelo movimento necessário das coisas, (os três poderes) seriam constrangidos, seriam forçados a ir de concerto". A experiência desmentiu o seu otimismo. Por isso Constant procurou, com o quarto poder, a coordenação e a arbitragem relativamente aos três outros. Note-se que, em 1958, a Constituição francesa se abeberou nesse mesmo ensinamento e previu um poder moderador no art. 5. ${ }^{\circ}$. Comentando-0, MAURICE DUVERGER relembra a Constituição brasileira de 1824 e louva a denominação que esta conferiu ao poder neutro de CoNSTANT:

"A expressão (poder moderador) é excelente, e descreve bem a função que o constituinte de 1958 atribuiu ao Presidente da República" ( $L a$ Cinquième Republique, P.U.F., Paris, 1960, p. 177/178).

Seguindo ConstaNT a Constituição do Império, no artigo 10, estabelecia:

"Os poderes políticos reconhecidos pela Constituição do Império do Brasil são quatro: o poder legislativo, o poder moderador, o poder executivo e o poder judicial".

Caracterizava esse poder moderador, cujo exercício incumbia ao Imperador, o art. 98 da Constituição.

"O poder moderador é a chave de toda a organização política, e é delegado privativamente ao Imperador, como chefe supremo da nação e seu primeiro representante, para que incessantemente vele sobre a manutenção da independência, equilíbrio e harmonia dos mais poderes políticos".

Ora, esclarecendo esse texto, Pimenta Bueno desenvolve magistralmente o tema:

"O poder moderador... é a suprema inspeção da nação, é o alto direito que ela tem, e que não 
pode exercer por si mesma, de examinar o como os diversos poderes políticos, que ela criou e confiou a seus mandatários, são exercidos. E a faculdade que ela possui de fazer com que cada um deles se conserve em sua órbita e concorra harmoniosamente com outros para o fim social, o bem-ser nacional; é quem mantém seu equilíbrio, impede seus abusos, conserva-os na direção de sua alta missão; é enfim a mais elevada força social, o órgão político mais ativo, o mais influente, de todas as instituições fundamentais da nação" (Direito Público Brasileiro; título V, cap. I, seção 1 , § $10^{\circ}$. Grifei).

Mais além, acrescenta, com profunda visão de estadista:

"O exercício do poder moderador é quem evita nos perigos públicos o terrivel dilema da ditadura ou da revoluçấo". (Ob. cit., n. ${ }^{\circ}$ 266. Grifei).

Só o pode exercer, contudo, quem estiver colocado em posição "superior a todas as paixões, a todos os interesses, a toda rivalidade". Por isso, não cabe "confundi-lo com nenhum outro poder, por isso mesmo que ele tem de inspecionar a todos, já sobre seu exercício próprio, já sobre suas relações recíprocas (Id. ibid.)

A história brasileira, e não apenas a do Império, comprova o acerto das observações de Pimenta BuENo. As paixões políticas e seu reflexo que atiça o conflito entre os poderes, não raro põem em risco o regime e a república. Para atenuá-las e desarmá-las, impõe-se uma intervenção exterior ao sistema político. Em muitas oportunidades dessa tarefa se desincumbiram as Forças Armadas. Seguramente, porém, haveria a ganhar se esse poder moderador fosse institucionalizado, como o era na Carta de 1824.

$O$ aspecto mais sutil da institucionalização de um poder moderador está no seu relacionamento com o poder executivo. $\mathrm{Na}$ Carta de 1824, se o Imperador exercia o poder moderador, era ele o chefe do Executivo que, todavia, era exercido pelos Ministros. E o que resultava do art. 102.

Com simplicidade e clareza, Pimenta Bueno elucida o ponto. E como sempre traça uma lição de sabedoria:

"Embora o imperante, o poder moderador, seja chefe do poder executivo, estes dois poderes são, e devem ser distintos; senão teríamos apenas uma fraseologia, e não uma realidade diferente. 
O imperante sem o ministro não é poder executivo, nem os atos deste poder têm vigor sem a assinatura ministerial, sem a responsabilidade, que é a garantia indispensável da sociedade.

Compreende-se que o poder moderador, chefe do poder executivo, deixa todos os detalhes, toda a administração secundária aos ministros, já para não distrair sua alta atenção fixada sobre os grandes interesses do Estado, já para que as pequenas questões, os pequenos interesses e paixões individuais pesem só sobre os ministros"... (Ob. cit., 276. Grifei)

Numa sociedade simples, regida por u'a máquina governamental também simples, PIMENTA BUENo já antevia o inconveniente de deixar sobre os ombros de um só homem, por mais capaz e qualificado que fosse, todo o peso dos problemas. Já previa e recomendava que se separasse o fundamental do secundário para que os problemas básicos do Estado não tivessem a sua solução prejudicada pelo acúmulo de questões menores. Ora, nisto está um defeito capital do presidencialismo. O Presidente da República é quem decide o maior e o menor. E freqüentemente a multidão dos pequenos interesses soterra-o, impedindo a atenção imprescindível ao que diz respeito, diretamente, aos superiores interesses da nação.

Entretanto, a distinção entre poder moderador e poder executivo não exclui que o chefe de Estado influa na orientação deste último. Como lhe cumpre nomear e demitir os ministros, cabe-lhe "mudar a marcha política e administrativa do governo em maior ou menor amplitude" (Id., n. ${ }^{\circ} 277$ ). Sem embargo, "na dependência de sua vigilância permanente estão as instituições, os progressos da civilização, as necessidades sociais, o bem-ser geral. É a alta direção, o espírito elevado, a apreciação da política e da administração superior, enfim o pensamento de impulsão que prefixa a harmonia de poderes, que tudo antevê, que previne a vigilância nacional", eis a missão própria do chefe de Estado (Id., n. ${ }^{\circ}$ 276).

Essa tarefa, por sua importância e responsabilidade, não poderia dispensar assessoramento, dir-se-ia em linguagem moderna. É o que afirmava Pimenta Bueno: "Quem poderá supor que qualquer dessas atribuições (do poder moderador) ... deva prescindir de maduro conselho e profundos esclarecimentos ?" (Id., n. ${ }^{\circ} 386$ ).

Para tanto é que a Constituição previu o Conselho de Estado (art. 137). Este fora, é certo, extinto pelo Ato Adi- 
cional de 1834. Entretanto, o restaurara a lei de 23 de novembro de 1841, que louva o mestre. Com efeito, "o Conselho de Estado é - segundo acentua - uma importante instituição que tem por destino auxiliar o governo e a administração nacional com suas luzes, experiência e opiniões ou pareceres; é o conselheiro, o coadjuvador de suas tarefas; e também o fiscal das competências administrativas, e o tribunal em matéria contenciosa de sua alçada" (Ob. cit., n. ${ }^{\circ} 385$ ).

Não são poucos, hoje, os que confundem a atividade do Conselho de Estado imperial com o exercício do poder moderador. Daí a sugestão de se restaurar esse poder, conferindo-o a um novo Conselho. A confusão é flagrante e a recomendação, inadequada. O Conselho do Império apenas assistia com seu parecer o exercício daquele poder pelo Imperador. E jamais poderia assumi-lo, eis que as funções inerentes ao poder moderador são próprias e peculiares à figura do chefe de Estado. Bem claro isto resulta do ensinamento do grande constitucionalista do Império.

Este, por outro lado, mostra a agudeza de sua análise ao examinar o poder executivo. Nisto vai muito de maioria de seus contemporâneos, alcança lições hodiernas. Aponta ele que o chamado poder executivo tem duplo caráter. Ora atua como "mero executor" - e então melhor se diria "poder administrativo"; ora "promove e imprime sua impulsão ao Estado" - quando merece a denominação de "governo ou poder governamental" (Ob. cit., n. ${ }^{\circ}$ 310). E aduz: "Com efeito, no primeiro caráter não é senão um simples administrador ou executor das leis respectivas e de suas conseqüências; no segundo é muito mais importante, é o governo do país, menos a confecção das leis e ação da justiça particular, e salva a inspecção do poder moderador e legislativo" (Id. ibid.).

Esta observação é de se aproximar da distinção que LOEWENSTEIN faz entre policy determination e policy execution. Este mestre, com efeito, no já clássico Political Power and the Governamental Process (Chicado, Univ. of Chicago Press, 2. ${ }^{a}$ ed., 1965), distingue entre policy determination, policy execution e policy control. A primeira corresponde exatamente ao que PIMENTA BUENo chamava de "poder governamental", a segunda ao que ele denominava de "poder executivo" (Cf. ob. cit., p. 43 e segs.). A obra do brasileiro é - recorde-se - um século anterior a do pensador estrangeiro.

Onde, porém, a atualidade do ensinamento de Pimenta BUENo salta aos olhos, é nas páginas que dedica à "oposição 
constitucional" (n. ${ }^{\circ} 361$ ) à qual opõe a "oposição sistemática" n. ${ }^{\circ}$ 362). Não basta resumi-lo, cumpre transcrevê-lo:

"Denomina-se oposição o complexo de vistas, de idéias ou princípios políticos que contraria as medidas, o pensamento político, ou mesmo administrativo do Ministério ou seus agentes, para que não prevaleçam, ou não continuem. A oposição pode ser manifestada pelas Câmaras legislativas, pela imprensa, pela opinião pública, pelos partidos ou indivíduos.

A oposição que se forma, que se agita, suas idéias por amor dos princípios, pela força de suas convicções sinceras, pelo serviço leal das instituições nacionais, e do país, que aspira os progressos sociais, a glória de sua pátria, a sua prosperidade, faz um importante e verdadeiro serviço.

Ela não terá jamais em vista desmoralizar os princípios reais do governo, os princípios da ordem, pelo contrário procurará esclarecer e orientar o pensamento público, conquistar a maioria. Não combaterá o governo em medida alguma útil, pelo contrário dar-lhe-á em tais casos o seu voto, pois que será favorecer ao bem público; não plantará um mal precedente ou mau princípio, pois temerá que reverta contra si própria, quando chamado ao poder; não iludirá o povo com vãs promessas para não ficar em falta e descrédito.

Esta oposição merece o nome de constitucional, pois que dirige seus esforços no intuito de fiscalizar a ação do governo, de reclamar contra a violação das garantias sociais, contra os prejuízos dos interesses públicos abandonados ou sacrificados.

Sua linguagem deve por isso mesmo, posto que enérgica, ser decente e sisuda, grave e refletida. É a oposição que conquista, que se prepara para o poder, que presta serviço valioso e cuja falta se faz sentir e adultera o sistema representativo, fazendo-o cair em frouxidão e marasmo, em uma atonia muito prejudicial, como já temos experimentado. O Ministério então abusa, nasce a descrença, e um descontentamento geral que enerva a vida política e pode dar resultados prejudiciais" (Ob. cit., n. ${ }^{\circ} 361$ ). 
Nem toda oposição, entretanto, segue esse alto padrão. Há outra que ele verbera:

"A oposição porém que se agita não por esses nobres sentimentos e convicções, sim por paixões mesquinhas ou pessoais, ou de pura ambição do poder, que não escolhe meios, que por sistema opõe-se sempre ao governo, ainda quando ele tem a razão de sua parte, ainda quando o seu pensamento ou medida é útil, essa é uma verdadeira calamidade pública. Ela desmoraliza a si própria e ao poder, os princípios do governo e da ordem pública, que procura rebaixar para alcançar mais depressa. Não reflete, não cura das futuras conseqüências, olvida-se do país, atende somente suas pequenas paixões, ou a sede do mando.

E a oposição, inimiga da tranquilidade do Estado, são ambiciosos ligados entre si, que prometem benefícios impossíveis, que jogam com a intriga e com as ilusões, que levados ao poder não tem forças de manter a ordem, e são muitas vezes vítimas de suas próprias doutrinas e maus princípios" (Ob. cit., n. ${ }^{\circ} 362$ ).

Está nesta contraposição o cerne da tão controvertida distinção entre "oposição" e "contestação". A última que mesmo na mais pura das democracias não pode ser admitida é a que não se forma nem se agita pelo serviço leal das instituições nacionais e do país. É a que tem sempre em vista desmoralizar os princípios reais do governo; os princípios da ordem. É a inimiga da tranqüilidade do Estado, a que sistematicamente procura rebaixar o governo, olvidando-se do país. Se a primeira é "democrática"; a segundo é, por excelência, "antidemocrática".

As idéias esparsas que se extraíram da obra máxima de Pimenta Bueno são suficientes para sublinhar o seu mérito e salientar a atualidade de suas lições, em tantos pontos fundamentais do chamado "modelo político brasileiro". Para bem assimilá-las, porém, é mister abeberar-se nos dois princípios que o mestre colocava como fonte de sua obra: ordem e liberdade (Ob. cit., prefácio).

Esse grande jurista e eminente homem de estado não foi professor. Entretanto, termina ele o prefácio do Direito Público Brasileiro com um apelo ao estudante: 
"A mocidade estudiosa é quem em breve terá de governar o Estado: nós outros somos a luz que se esmorece, que se finda, que se apaga; ela é a luz que se acende, que cresce, e que vai resplandecer; receba agora nosso trabalho, estude e logo depois o corrija, acrescente; e aperfeiçoado o ofereça à mocidade que tem de sucedê-la. Levemos nossa pedra, segundo nossas forças, à pirâmide da pátria".

Assim se fez a glória e também a grandeza da Academia do Largo de São Francisco. 